\title{
Reduced order modeling in topology optimization of vibroacoustic problems
}

\author{
Creixell Mediante, Ester; Jensen, Jakob Søndergaard; Brunskog, Jonas; Larsen, Martin
}

Published in:

Journal of the Acoustical Society of America

Link to article, DOI:

$10.1121 / 1.4989307$

Publication date:

2017

Document Version

Peer reviewed version

Link back to DTU Orbit

Citation (APA):

Creixell Mediante, E., Jensen, J. S., Brunskog, J., \& Larsen, M. (2017). Reduced order modeling in topology optimization of vibroacoustic problems. Journal of the Acoustical Society of America, 141(5), 4035-4035. https://doi.org/10.1121/1.4989307

\section{General rights}

Copyright and moral rights for the publications made accessible in the public portal are retained by the authors and/or other copyright owners and it is a condition of accessing publications that users recognise and abide by the legal requirements associated with these rights.

- Users may download and print one copy of any publication from the public portal for the purpose of private study or research.

- You may not further distribute the material or use it for any profit-making activity or commercial gain

- You may freely distribute the URL identifying the publication in the public portal 


\section{Reduced order modeling in topology optimization of vibroacoustic problems}

There is an interest in introducing topology optimization techniques in the design process of structuralacoustic systems. In topology optimization, the design space must be finely meshed in order to obtain an accurate design, which results in large numbers of degrees of freedom when designing complex 3D parts. The optimization process can therefore become highly time consuming due to the need to solve a large system of equations at each iteration. Projection-based parametric Model Order Reduction (pMOR) methods have successfully been applied for reducing the computational cost of material or size optimization in large vibroacoustic models; however, new challenges are encountered when dealing with topology optimization. Since a design parameter per element is considered, the total number of design variables becomes very large; this poses a challenge to most existing pMOR techniques, which suffer from the curse of dimensionality. Moreover, the fact that the nature of the elements changes throughout the optimization (material to void or material to air) makes it more difficult to create a global basis that is accurate throughout the whole design space. In this work, these challenges are investigated and different approaches to achieving an efficient reduction technique for such problems are discussed. 